New Zealand Journal of Employment Relations, 45(2): 77-88

\title{
Economies of mana and mahi beyond the crisis
}

\author{
MATTHEW SCOBIE* and ANNA STURMAN**
}

\begin{abstract}
In this short article, we explore the implications of Covid-19 and its response for employment in Aotearoa | New Zealand, focusing on the potential effect in Māori communities. To prevent the foreclosure of possible alternative futures, we emphasise the need to envisage economies in different ways, and the potential for alternative understandings of work within these visions. We argue that, rather than creating conditions for economic transformation in Aotearoa | New Zealand, Covid-19 has merely revealed preexisting conditions with strong transformative potential. The pre-existing conditions that we will focus on in this paper are the enduring understandings of economy and work within Te Ao Māori (the Māori world) and at the meeting place of worlds represented by Te Tiriti | The Treaty of Waitangi. We write as an exploratory partnership between a Ngāi Tahu/Pākehā scholar living and working in the Ngāi Tahu takiwā (territory) and a Pākehā scholar living and working on the lands of the Gadigal people of the Eora Nation.
\end{abstract}

Keywords: Covid-19, pandemic, economies of mana, care, Māori, women, employment relations

The Covid-19 pandemic is a global health crisis that will continue to cause severe economic consequences long after the initial shocks. Estimates and headline figures on employment vary widely but with evidence to suggest that, as a result of Covid-19, Māori are being laid off at four times the rate of Pākehā (Fyers et al., 2020). Tokona te Raki, and Business and Economic Research Limited (BERL) found that just over 169,000 Māori are currently employed in industries likely to be directly affected by Covid-19 and its response. This is half the Māori workforce, and these are disproportionately youth workers (Tokona te Raki, 2020). They refer to this as a "generation disrupted" (Tokona te Raki, 2020, p. 11). At the same time, Māori communities have worked together to fight against the virus and its impacts in care-full ways (Kukutai et al., 2020). A prominent example of this has been the iwi community checkpoints established to protect communities from the pandemic, working from the premise that those groups had a duty to protect (Ngata, 2020).

World over, governments have attempted to balance the need for continued health measures with the realities of capitalist economic imperatives, namely the requirement for continual growth. New Zealand's economy is structured around key export industries which will be particularly affected by the immediate downturn and its ongoing effects, including tourism, agriculture and higher education. Due to the economy's reliance on export-driven growth, the unavoidable recession caused by the global closure of markets will be felt widely across New Zealand for years to come. The government has moved to soften

\footnotetext{
* College of Business and Law, University of Canterbury, New Zealand

** PhD candidate, Department of Political Economy, University of Sydney, Australia
}

Acknowledgements: The authors would like to acknowledge the support of the special issue editor and anonymous reviewer towards improving the paper. The paper has also benefitted from the support of colleagues at the University of Canterbury and University of Sydney. 
the social impacts of the immediate economic shocks through emergency funding, including funding for some direct social provisioning (for example, emergency housing) and measures that effectively represent the temporary nationalisation of some industries through extensive wage subsidisation. Despite the halt to 'normal' economic functioning which Covid-19 has necessitated, the mostly un-waged and often unseen labour necessary to the ongoing function of our societies (sometimes referred to as 'reproductive labour' [Bhattacharya, 2017; Munro, 2019]) has continued as normal in homes and communities across Aotearoa. The parts of this labour that are represented in the formal economy, including forms, such as healthcare, cleaning services and food preparation, are typically included in the range of functions labelled as 'essential' work. For the purposes of this paper, however, we are interested specifically in the labour occurring outside the auspices of the formal economy and the government's mandated reach.

We take as our point of departure the pioneering work of New Zealand's own Marilyn Waring, who opened and has since continued a discussion about un- and under-valued labour in the formal economy. Waring's (1988) analysis focused on the contribution of women to the economy through labour that went unrecognised and unrewarded by wages. We begin in a similar vein by focusing on labour that is at present unvalued within the formal economy, however, the parameters of our discussion differ from those of Waring in two key ways. Firstly, we aim our discussion at Māori rather than women's labour. Secondly, we do not focus on the impact of this labour on the 'formal economy' in the tradition of Waring. In line with Te Maire Tau's characterisation, we refer to formal and informal economies within the Pākehā sphere of authority as the settler-colonial economy (Tau, 2016; Tau \& Rout, 2018) and our intention is to deal with this economy as a secondary element within our analysis. Our primary focus is exploring the transformative potential of Māori labour that is situated within and particular to Māori economies, or economies of mana.

In response to Covid-19, Māori economies have undertaken the caring work and labour necessary to sustain communities through the initial stages of the pandemic. These provide us with an opportunity to explore the possibilities inherent in these economies and the ways they may provide leadership and otherwise interact with the settler-colonial economy. We argue that these alternative spheres of authority, economic production and labour provide examples of resilient and sustainable economies, and as such will be of great interest to those attending to the need for dramatic, global rearticulation of capitalism from its present waning form(s). Further, this could be a decisive moment in the evolution of Treaty partnership (Kukutai et al., 2020). We will discuss the response to Covid-19 in light of the historical experiences and mobilisations of Māori communities during prior economic and other crises through three simplified perspectives on economies and employment. The conventional perspective tends to focus on Māori businesses and workers within the capitalist economy. The recent iwi community checkpoints, however, can be seen as a meeting place between two worlds and therefore a conventional and an alternative perspective. The alternative perspective focuses on economies of mana and mahi beyond the checkpoints. These perspectives are inspired by the three spheres of authority set out in the report of Matike Mai Aotearoa (2016) - a kāwanatanga sphere (government) a rangatiratanga sphere (Māori sovereignty), and a relational sphere. As such, these are not mutually exclusive, but overlap in their complexity and diversity towards a fuller picture. These are illustrated for simplicity below. 
Conventional perspective Settler-colonial economy with paid wage labour.
Meeting place: where economies of mana confront the settlercolonial economy.
Alternative perspective Māori economies of mana and mahi based on hau

As our entry point to such discussions, we first explore the history of economic restructuring in New Zealand and the ways in which Māori have been disadvantaged within these broad programs of change as a cautionary tale for Covid-19 respondents. We then discuss the Treaty and the implications for Māori economies within this, including the need for both discursive and material explorations of diverse economic possibilities. Following this, we set out three of the possible perspectives on Māori economies and employment within responses to Covid-19. Here, we emphasise alternative perspectives on employment and value(s) within Māori economies drawing from Mānuka Hēnare's work on economies of mana. We do so to open up the potential for alternative futures based on alternative conceptions of work and value. We conclude with opportunities for future research and practice and argue that now is a crucial time to think more carefully through Treaty partnership and alternative economies and employment.

\section{Economic restructures of the past}

In this paper, we seek to characterise periods of significant economic reform in New Zealand's history, not through the lens of economy-wide or macroeconomic efficiencies or tendencies, but instead to contextualise them as state-led measures that have been presented as 'for the good of all' and yet often disproportionately affected Māori communities in negative ways (Kukutai et al, 2020). Covid-19 and the state-led response to the connected economic shocks must be examined as the latest period of economic restructure that could either have debilitating effects on Māori, or provide the opportunity for transformation through recognition of the Treaty and consequently of the Māori sphere of authority.

The initial waves of land redistribution constitutive to the colonisation process are perhaps the quintessential example of dramatic economic reforms that had negative effects on Māori. Early settler state legislation, including the New Zealand Settlements Act 1863, the Public Works Land Act 1865, and then a later wave including the Native Lands Purchase Act 1892 and the Lands Improvement and Native Lands Acquisition Act 1894 facilitated this siphoning of Māori land through the state to its role as the basis of the domestic economy. Māori land losses achieved multiple purposes including funding the formation of the government (Hooper \& Kearins, 2004) and enabling the land-use framework for New Zealand's primary export industries (Wynyard, 2016), which, in turn, created employment for a new class of small farmers and, thus, the basis of New Zealand's settler-colonial economy. But Māori neither benefitted nor had a voice in either process. The role of land confiscations and private property regimes in forcibly moving the balance of power in early New Zealand, and growing the settler-colonial economy at the expense of Māori economies of mana continues to be discussed as the impacts live on.

Another round of economic reforms was precipitated by class struggle emerging in the 1920s Depression era and then the effects of World War 2 (Sutch, 1966). These involved the construction of the welfare 
state, namely the introduction of social security measures and a focus on full employment designed to insulate New Zealanders from the worst vagaries of the global capitalist economy. Militant labour movements were inoculated against through their incorporation into the state as the first Labour Party, successfully relegating political economic contestation to the political sphere and ringing in an era of corporatist bargaining between the state, labour and capital. This approach, however, relied on the continued strength of exports. The deepening reliance on agricultural exports and consequent need for expanded access to land inevitably led to further legislative expropriation of Māori land as a means of sustaining the economy. The combination of the Town and Country Planning Act 1953 and the Māori Affairs Amendment Act 1967 resulted in a mass migration by external design of Māori from rural land that they owned to urban areas where they had to rent (Tau, 2016). As intended, this had the effect of making Māori reserve land available for the mostly settler-colonial agricultural economy and propelling Māori into cities to become a labour supply for the mostly settler-colonial industrial economy. This general process of rural displacement and corresponding increases in urbanisation is a spatial dynamic constitutive to capitalism (Smith, 2008). The specificity of this process in Aotearoa, with changes being enacted for the 'greater good' of New Zealanders, still overwhelmingly disadvantaged Māori and continued to negate the ability for economies of mana and ideas of work within to flourish (once again).

The structural adjustment period of the 1980s and 90s wrought fundamental changes in New Zealand's economy and employment, which form the background to our contemporary moment. In contrast to the 1930s economic reforms, which had been driven by a strong working-class movement at home and abroad, this wave of reform was the local edition of a global rebalancing of the scales in favour of capital (Jesson, 1987). Changes to the Reserve Bank's legislated priority from full employment to low inflation and the legislative changes to employment relations altered how New Zealanders work, at the same time as the social security measures of earlier economic reforms were withdrawn in favour of market-based provision. The Employment Contracts Act 1991 replaced the established labour relations framework with a fragmented form of employment contracting, namely by creating individualised employment relationships. This has significantly weakened the bargaining power of labour and reinforced the ideology of 'individual responsibility' over solidarity and collective bargaining. As set out by Jane Kelsey (1995), these and other elements of the restructure altered the very fabric of New Zealand society. As part of broader government strategies to reduce potential fiscal liabilities (for example the sale of state-owned enterprises and restructuring of foreign-owned debt) in the early 1990s, the government attempted to set upper limits on possible Treaty settlements via a 'fiscal envelope' strategy (Fisher, 2017). This strategy attempted to set the parameters within which Māori self-determination could occur and, again, Māori were placed at a disadvantage by state-led measures rather than being accorded the place of full Treaty partners. Te Tiriti/The Treaty and the potentialities it contains for alternative Māori economies have repeatedly been subordinated to the settler-colonial economy.

Covid-19 and the accompanying loss of particular industries and employment creates a major challenge and potential watershed for thinking around the contemporary economy and work. Despite what is often presented with an aura of inevitability, inequitable economic restructures are never predetermined and fixed, but the result of contestation. Fundamental reshaping in the wake of Covid-19 has begun, if only in the form of a suddenly broader horizon of possibility. While discussions around economic transformations have proliferated in recent years, including automation, job losses, and recurring crashes, Covid-19 appears to have brought forward the time of reckoning. Stirrings of imminent change in Aotearoa include 'shovel ready projects' at a level of state intervention not seen for some time. Many voices have been calling for transformative change in the contemporary context both within (Wade, 2020) and outside of formal processes as part of growing social movements and community-led contestation (Kukutai et al., 2020). The committee hearings outlined in Wade (2020), for example, 
illustrate some of the wider debates and divisions regarding Aotearoa New Zealand's future. We argue that transformative change has already begun as the opening up of discursive and material spaces for alternative economic possibilities. Today this is rooted in the constitutional status of the Treaty and flowering in the existing Māori economies that have mobilised in response to Covid-19. We will set out a theoretical discussion of these Māori economies before proceeding with analysis of the Covid-19 moment.

\section{Diverse economies of mana}

Many critics have pointed out that what is commonly understood in mainstream discourse as 'the Māori economy' is more usually Māori businesses in a global capitalist economy (see e.g. Bargh, 2015; Tau, 2016; Amoamo et al., 2018; Dell et al., 2018; Tau \& Rout, 2018). These dominant perspectives of the 'Māori economy' fail to recognise, firstly, the difference between Māori-owned businesses within the capitalist economy and Māori economies, and secondly, the diversity within Māori economies (Amoamo et al., 2018). One serious constraint in theoretical and material conceptions of 'the economy' is when we consider it as a 'unity', 'singularity' and 'totality' which together constitute the economy 'as an object of transformation that cannot be transformed" (Gibson-Graham, 1996, p. 253). Within this (narrow) understanding there is only one form of employment: paid wage labour.

In contrast, Te Tiriti/The Treaty of Waitangi enables us to think at least about dual economies in Aotearoa New Zealand. Godfery (2016) explores the constitutional status of the Treaty in 1840 and today, and argues that the Treaty reaffirms Māori constitutional power through tino rangatiratanga (unfettered chieftanship), and kāwanatanga (governorship) confers a new power on the settlers. Within a context in which the empowering system is a Māori constitutional system with Māori law, then the concept of mana in the pre-1840 constitutional system becomes rangatiratanga in the post-1840 system, and can be conceptualised as a partnership in which rangatiratanga and kāwanatanga constitute separate sites of power. A key point here is the concept of mana as key to a pre-1840 constitutional system because this has clear links with mana being a central aspect of the pre-Treaty and contemporary Māori economy. Economies of mana in the past, present and future have been the subjects of (re)exploration in recent years.

Hēnare (2014) argues that while the Employment Contracts Act 1991 claimed to ensure an efficient 'labour market' in New Zealand, this labour market and its principles, values and ethics represent a particular world view. Instead, he asserts that the Māori economy served, and continues to serve material and spiritual needs and this Māori tribal mode of production gives rise to "economies of mana". Hēnare (2014) presents features of the capitalist economy that can be seen as anathema to Māori notions of knowing and organising; these include the commodification of labour, valuing capital over labour, and narrowly defined pursuits of individual utility maximisation. In his critique of employment relations, Hēnare (2014) argues, for example, that in the mainstream model workers are forced to accept fluctuating compensation irrespective of collective needs (Hēnare, 2014). In contrast, Māori modes of production embody a labour relationship that involves gift-making and exchange. Human labour and culture are given for continued employment and wages and this incorporates the notions of tapu (sacred), mauri (life force) and mana (authority/prestige) (Hēnare, 2014). Māori philosophy gives dignity (tapu and mana) to people (labour) over capital (Hēnare, 2014). In this framework, workers are not instruments or objects in the production process with the value of their labour measured by the wage-relation, but are imbricated in value creation and exchange in diverse ways. He also suggests that hau (vitality of a person, place or 
object) could be a contribution of Polynesian thought and practice towards healthy labour relations, as a theory of solidarity.

In addition, both Amoamo et al. (2018) and Dell et al. (2018) point out that in contrast to the capitalist tendency towards accumulation, economies of mana are instead focused on wealth distribution. Manaaki-tanga means to give mana and those with access to resources maintain and enhance their own mana by maintaining and enhancing the mana of others. Rout et al., (2017) explore this using the Ngāi Tahu tîtī economy as an example and argue that exchange is/was largely embedded in social relations with a utilitarian component and mana playing a regulatory role. This economy was, then, fundamentally based on and regulated by mana, with employment relations based on manaakitanga. Hēnare (2014) terms this an economy of mana - a mode of production based on affection that considers the needs of ancestors and descendants, and collective wellbeing over profit. He argues that these economies have not only survived, but have also influenced the mode of production within the settler-colonial economy, a point we return to in the conclusion.

Dell et al. (2018) extend Hēnare's (2014) economy of mana and argue that there is yet to be a clear vision of Māori economic futures built upon economies of mana. A key contribution of their paper is the assertion that an economy of mana is "an economic system in which decisions regarding investment, production, consumption and wealth distribution are influenced by the interplay of mana-enhancing interactions between people and the environment" (Dell et al., 2018, p. 55). Amoamo et al. (2018) extend the thinking around a Māori economy of mana to diverse Māori economies by drawing from, among others, Gibson-Graham (1996). They argue that the dominant definition and discourse of Māori economy and enterprise is problematic "primarily because it contradicts the heterogeneity of how Māori think about themselves, their modes of social organisation, the resources available to them, how they see themselves connected to those resources and therefore how they use those resources" (Amoamo et al., 2018, p. 68). This leads to their second key contribution that Māori economies are systems that serve people rather than economies served by people. This establishes a creative and organic interdependence among economies, communities and peoples. Maria Bargh $(2011 ; 2012)$ has pursued this line of thought and argues that a diverse economies approach allows for a more complex and rich picture, where Māori modes of production are not necessarily evidence of capitalist agendas, but represent diverse ways of being powerful. If Māori are to implement economies of mana within their sphere(s) of authority and form clarifying visions of Māori economic futures, then a first step towards enabling these generative and expansive modes of production/life is the dislodgement of the discursive dominance of capitalism through engagement with those material economies of mana already in existence (Amoamo et al., 2018). This paper is a contribution to this effort, using the rupturing moment of Covid-19 as an opportunity to agitate the discursive dominance of capitalism and reveal the material foundations for burgeoning economies of mana.

\section{Employment relations as part of diverse economies during and beyond Covid-19}

Now that we have created a discursive space to think about the material implications for diverse Māori economies, we explore whether Māori economies could be transformative on a number of fronts. Firstly, they stand apart from what is currently considered 'the economy' as a sphere of Māori influence/sovereignty and thus represent a reversal of the historic subsumption of Māori into the settlercolonial economy. Secondly, these economies could be transformative for the settler-colonial economy as areas of collective social provisioning develop according to the collectively determined needs of communities rather than in pursuit of profit. It remains to be seen how the government's current 
reordering of work through state-led programs could also contribute to such a transformation. In the meanwhile, we can think of the impacts from Covid-19 on Māori economies and employment in at least three overlapping, and by no means mutually exclusive ways: a conventional economic perspective; a meeting between perspectives; and an alternative perspective. Thinking through these issues in different ways creates implications for policy responses, which we discuss in the final section.

The first way that we can think about impacts from Covid-19 on Māori economies and employment is what we tend to hear more about because it fits in a more conventional, but necessary nonetheless, narrative. This includes: large-scale job losses (Johnsen, 2020; Te Karere, 2020); inequities in response, either too much (Soper, 2020) or too little (Dunlop, 2020); and Māori businesses struggling (RNZ, 2020). It also includes the disproportionate and negative impacts of restructuring on Māori employment (Naepi \& McAllister, 2020), because of workforce representation in export industries (Tokona te Raki, 2020). This tends to be the mainstream perspective on the Māori economy, that is, businesses and employment relations featuring Māori within the global capitalist economy. This approach discursively and materially reinforces the totality of a single all-encompassing economy with one form of employment relation wage labour - and, therefore, reinforces a response to improve but entrench the status quo. While we caution against uncritical reception of this approach, it is clear that such analysis is necessary in order to achieve immediate improvements in people's lives. The calls for more participation in response and recovery planning within some of these perspectives (see, for example, Brockbank et al., 2020; Hitchcock, 2020) are also crucial in enabling possibility within and beyond the status quo.

The second way we can think about impacts and responses to Covid-19 is at a 'meeting place' of the settler-colonial economy and economies of mana. These are represented well at the iwi community checkpoints set up to directly remind visitors of alert levels in order to keep communities safe from Covid-19 (Ngata, 2020). Ngata (2020) discusses these as a Māori duty to protect that has often benefitted Māori and the country more broadly, and Harris and Williams (2020) argue that, contrary to some claims, there is a sound legal foundation for these checkpoints. We argue that these checkpoints represent a meeting place of laws, economies and worlds (Pasternak, 2017), because at and beyond iwi checkpoints lie economies of mana. These are based on mutual aid that represents a hidden present and alternative future for understanding economies, and therefore employment relations within. Individuals, whānau, hapū and iwi volunteer their time and energy to stand at this meeting place to protect the things they hold dear and, while this labour of love would not be recognised in conventional measures of GDP and employment, it is labour nonetheless. It is labour that maintains the dignity of workers with kinship obligations that extend far beyond the wage relation. These practices are continuations of an enduring duty to protect (Ngata, 2020) that has seen different iterations in recent times, with examples such as community support after natural disasters (Kenney \& Phibbs, 2015), and terror attacks (Daly, 2019). Iwi and Māori owned businesses are also present at this meeting place of worlds when they operate within a global market economy, but have internal dynamics that recognise economies of mana and employment relations based on manaakitanga (Bargh, 2011; 2012). For example, Te Rūnanga o Ngāi Tahu directed their waged-employees to spend time calling iwi members to check in on their wellbeing and Māori fishing companies slashed prices and donated stock for iwi to support their people (Hurihanganui, 2020).

The third perspective emanates from the (physical and metaphorical) other side of these checkpoints, being the contemporary work and economic relations within what can be considered economies of mana. Kukutai et al. (2020) provide a summary of some of these activities in their call for Māori, iwi, hapū and whānau participation in recovery. These include the aforementioned checkpoints (Ngata, 2020), the preparation and delivery of care packages (Tyson, 2020), and a history of Māori care responses after disaster, like Ngāi Tahu's involvement in earthquake response and recovery (Nation, 2017). In addition, 
although Te Rūnanga o Ngāi Tahu's formal businesses and employment relations have been in the media because of large scale job losses during the crisis (RNZ, 2020), the iwi itself and the hapū, whānau and marae that make up the iwi have been quietly labouring away. This includes calling to check on the wellbeing of elders, delivering care packages of food, hygiene products and firewood, using marae facilities to prepare large amounts of food for distribution, funding and distributing small hardship grants, organising Covid-19 testing, vaccinations and other medical support, and connecting with warmth (Te Pānui Rūnaka, 2020). Aside from being particularly equipped for crisis response, Māori economies are also made up of countless hours of labour on and around marae (meeting places) and mahinga kai (food gathering). These are all forms of labour that contribute to Māori economies but are not recognised within conventional metrics and employment relations, hence our drawing of a parallel between this labour, the 'women's work' studied by Waring, and the large amounts of un- and under-valued labour that sustain the settler-colonial economy. While they are not formally recognised, they are essential to Māori economies and enable Māori communities to come together to weather these crises.

We argue that all three of these perspectives and their interrelations with one another are important to understanding the past, present and future of economies in Aotearoa | New Zealand. We make no claim as to which is more important, but rather suggest they all be explored together in their diversity to imagine and create positive futures. As Kukutai et al. (2020) and others argue, these ideas and practices also present opportunities to rebuild New Zealand together in partnership. Rangatiratanga (selfdetermination) guaranteed by Te Tiriti | The Treaty both promises and demands this. Treaty partnership requires it.

\section{Concluding thoughts}

Conventional economic responses tend to reinforce conventional economic perspectives, and we have gestured toward how conventional economic responses over the course of New Zealand's history have tended to structurally disadvantage Māori. As the harbinger of New Zealand's next economic restructure, Covid-19 has opened up the opportunity to imagine new futures based on enduring practices and values, at the same time as honouring the Treaty. In this short article, we have attempted to further open discursive spaces for diverse understandings of economy and work that exist and are flourishing. We also note, in closing, however, the uneasy coexistence of such diverse economies with(in) the capitalist economy and suggest that this challenge will require further exploration. Acknowledging alternative spheres of authority and economic production and labour relations within is the first step in a longer journey of tackling questions of work and the future of capitalism in a rapidly changing world. How best might we structure our collective labour within each sphere, and in partnership, so that they both flourish together according to Te Tiriti | The Treaty?

In previous historical shocks, different value(s) that we can create together through diverse Māori economies have been obscured or ignored beneath a single narrow understanding of what the economy and employment are. These have tended to maximise the financial profits of a few rather than the wellbeing of the many, with ample evidence that these top-down restructures disproportionately and negatively impact Māori (Cochrane \& Pool, 2017; Tokona te Raki, 2020). But this path is not inevitable, organising from the ground below, honouring Treaty partnership, and recognising and implementing Māori values and perspectives are shaping a new future for all. Māori economies of mana have both the potential to be autonomous and to provide guidance for those planning for change in the settler-colonial economy currently in crisis. Key questions that we do not have the space to address here but must be considered going forward are therefore: 
New Zealand Journal of Employment Relations, 45(2): 77-88

- How might economies of mana evolve in line with the broader structural transformations taking place within the global capitalist economy?

- What are the forms of labour within economies of mana based on meeting needs according to intergenerational more than human kinship obligations?

- How might these be recognised and scaled out to create more fulfilling work and economic relations for Māori and for all?

- How can Māori economies provide leadership for other sectors in creating resilient and sustainable economies?

The possibilities to pave other paths exist and are emerging. Iwi checkpoints and other care-full responses based on mana (authority) and tikanga (normative ethics) are exercises in rangatiratanga (selfdetermination). Within these possibilities lie alternatives for employment relations based on manaakitanga (maintaining and enhancing the mana of others). These exercises are opportunities for partnership and calls by Māori to demand parts in, not just restarting the economy after this crisis, but imagining and creating hopeful alternatives are being heard. While past disasters and shocks have been occasions that have narrowly defined what an economy and employment is, this is an opportunity to imagine, create and implement alternative visions of relationality based on Māori traditions for the benefit of all New Zealanders. To return to Marilyn Waring's contribution, we argue that while Māori, women's, and Māori women's labour have all been historically excluded from formal recognition in 'the economy', it may well be Māori, women, and Māori women whose work leads us all towards alternative futures (see e.g. Bargh, 2015; Amoamo et al., 2018; Dell et al., 2020). To conclude, Waring has asked "what if women counted?"; we support and extend this by asking "what if Māori counted?" but vitally, "what if we counted in Māori?"

\section{References}

Amoamo, M., Ruwhiu, D., \& Carter, L. (2018). Framing the Māori economy: The complex business of Māori business. MAI Journal, 7(1): 66-78.

Bargh, M. (2011), The triumph of Maori entrepreneurs or diverse economies? Aboriginal Policy Studies, $1(3), 53-69$

Bargh, M. (2012), Rethinking and re-shaping indigenous economies: Māori geothermal energy enterprises. Journal of Enterprising Communities: People and Places in the Global Economy, 6(3), 271-283

Bargh, M. (2015), A hidden economy: Māori in the Privatised Military Industry. Huia Publishers.

Bhattacharya, T. (2017). Introduction: Mapping Social Reproduction Theory. In T. Bhattacharya (ed.), Social Reproduction Theory: Remapping Class, Recentering Oppression (pp. 1-20). Pluto Press.

Brockbank, T., Archer, E., Pole, S., \& Cotter-Tait, S. (2020). Building equity into the infrastructure-led recovery for Māori and Pasifika. The Spinoff. https://thespinoff.co.nz/atea/01-06-2020/buildingequity-into-the-infrastructure-led-recovery-for-maori-and-pasifika/\#top 
New Zealand Journal of Employment Relations, 45(2): 77-88

Cochrane, W., \& Pool, I. (2017). Māori in New Zealand's contemporary development. Policy Quarterly, 13(June), 47-54.

Daly, M. (2019). Ngāi Tahu open marae to families of Christchurch mosque shooting victims. Stuff. https://www.stuff.co.nz/national/christchurch-shooting/111415971/ngi-tahu-open-marae-tofamilies-of-christchurch-mosque-shooting-victims

Dell, K., Staniland, N., \& Nicholson, A. (2018). Economy of Mana: Where to next? MAI Journal, 7(1): 51-65.

Dunlop, M. (2020). Government urged to put Māori at forefront of Covid-19 planning. RNZ (Radio NZ). https://www.rnz.co.nz/news/te-manu-korihi/413660/government-urged-to-put-maori-atforefront-of-covid-19-planning

Fisher, M. (2017). The Ngai-Tahu Treaty Settlement Negotiation with the Crown: Key Players and Background. Te Karaka, Makariri/Winter(86). https://ngaitahu.iwi.nz/our_stories/the-ngai-tahutreaty-settlement-negotiation-with-the-crown-key-players-and-background-tk75

Fyers, A., Parahi, C., Kilgallon, S., \& Rodrigues, F. (2020). Deep trouble: A historic unemployment crisis has begun. Stuff. https://interactives.stuff.co.nz/2020/06/unemployment-crisis-covid-economicrecoveryl

Gibson-Graham, J. K. (1996). The end of capitalism (as we knew it): A feminist critique of political economy. Blackwell Publishers.

Godfery, M. (2016). The political constitution: from Westminster to Waitangi. Political science, 68(2): 192-209.

Harris, M., \& Williams, D. (2020). Community checkpoints are an important and lawful part of NZ's Covid response. The Spinoff. https://thespinoff.co.nz/society/10-05-2020/communitycheckpoints-an-important-and-lawful-part-of-nzs-covid-response/

Hēnare, M. (2014). The economy of mana. In D. Cooke, C. Hill, P. Baskett \& R. Irwin (eds.), Beyond the free market: Rebuilding a just society in New Zealand (pp. 65-69). Auckland, New Zealand, Dunmore.

Hitchcock, J. (2020). The effects of the Covid-19 recession will hit Māori hardest. The Spinoff. https://thespinoff.co.nz/atea/08-04-2020/the-effects-of-the-covid-19-recession-will-hit-maori$\underline{\text { hardest/ }}$

Hooper, K., \& Kearins, K. (2004). Financing New Zealand 1860-1880: Māori land and the wealth tax effect. Accounting History, 9(2), 87-105.

Hurihanganui, T. A. (2020). Kaimoana distributed to iwi through collaboration with Sealord, Moana. RNZ (Radio NZ). https://www.rnz.co.nz/news/national/417593/kaimoana-distributed-to-iwi$\underline{\text { through-collaboration-with-sealord-moana }}$ 
New Zealand Journal of Employment Relations, 45(2): 77-88

Jesson, B. (1987). Behind the mirror glass: The growth of wealth and power in New Zealand in the eighties. Penguin Books (N.Z.) Ltd.

Johnsen, M. (2020, April 15). Fears Māori unemployment rates will surge after lockdown lifts. RNZ (Radio NZ). https://www.rnz.co.nz/news/national/414325/fears-maori-unemployment-rates$\underline{\text { will-surge-after-lockdown-lifts }}$

Kelsey, J. (1995). Economic Fundamentalism - The New Zealand Experiment: A world model for structural adjustment? Pluto Press.

Kenney, C., \& Phibbs, S. (2015), A Māori love story: Community-led disaster management in response to the Ōtautahi (Christchurch) earthquakes as a framework for action. International Journal of Disaster Risk Reduction, 14(1): 46-55.

Kukutai, T., Moewaka Barnes, H., McCreanor, T. \& McIntosh, T. (2020). Recession hits Māori and Pasfika harder. They must be part of planning New Zealand's COVID-19 recovery. The Conversation. https://theconversation.com/recession-hits-maori-and-pasifika-harder-they-mustbe-part-of-planning-new-zealands-covid-19-recovery-137763

Matike Mai Aotearoa. (2016). The report of Matike Mai Aotearoa - The independent working group on constitutional transformation. https://nwo.org.nz/wpcontent/uploads/2018/06/MatikeMaiAotearoa25Jan16.pdf

Munro, K. (2019). "Social Reproduction Theory", Social Reproduction and Household Production. Science \& Society, 83(4), 451-468.

Naepi, S., \& McAllister, T. (2020). As universities restructure, Māori and Pacific researchers are being put at risk. The Spinoff. https://thespinoff.co.nz/atea/21-05-2020/as-universities-restructuremaori-and-pacific-researchers-are-being-put-at-risk/

Nation, D. (2017). One year on. Te Karaka, Makariri/Winter(86). https://ngaitahu.iwi.nz/our_stories/one-year-on-tk76/

Ngata, T. (2020). COVID-19 and the Māori duty to protect. Overland Journal. https://overland.org.au/2020/05/covid-19-and-the-maori-duty-to-protect/

Pasternak, S. (2017). Blockade: A Meeting Place of Law. In P. McFarlane and N. Schabus (eds.), Whose Land is it Anyway? A Manuel for Decolonization (pp. 32-35). Federation of Post-Secondary Educators of BC.

RNZ (Radio NZ). (2020). Ngāi Tahu Tourism to cut 300 jobs and puts most businesses into hibernation. https://www.rnz.co.nz/news/business/416013/ngai-tahu-tourism-to-cut-300-jobs-and-puts-mostbusinesses-into-hibernation

Rout, M., Reid, J., Te Aika, B., Davis, R., \& Tau, T. (2017), Muttonbirding: Loss of executive authority and its impact on entrepreneurship. Journal of Management \& Organization, 23(6), 857-872. 
New Zealand Journal of Employment Relations, 45(2): 77-88

Smith, N. (2008). Uneven Development: Nature, Capital, and the Production of Space. The University of Georgia Press.

Soper, B. (2020, April 2). Barry Soper: \$56 million for Māori exposes naked politics of Covid outbreak (opinion). Newstalk ZB. https://www.newstalkzb.co.nz/opinion/barry-soper-56-million-formaori-exposes-naked-politics-of-covid-outbreak/

Sutch, W. B. (1966). The Quest for Security in New Zealand 1840 - 1966. Oxford University Press.

Tau, T. (2016). Sketching a tribal economy: Draft discussion document. University of Canterbury.

Tau, T., \& Rout, M. (2018). The tribal economy. The Journal of New Zealand Studies, (NS27), 92-109.

Te Karere. (2020). Mãori are among the worst affected economically by COVID-19. Te Karere. https://www.tvnz.co.nz/shows/te-karere/home/m ori-are-among-the-worst-affectedeconomically-by-covid$\underline{\text { 19?fbclid=IwAR2nq7fkxSQMC6Y_izYGkdy2p9bi5sHeqViTA7W9mtrAiLBlws2XutBIpZM }}$

Te Pānui Rūnaka. (2020). Te Pānui Rūnaka: A monthly newsletter of Käi Tahu news, views and events. https://tepanui.co.nz/

Tokona te Raki. (2020). Ka whati te tai: a generation disrupted. Report prepared for Tokona Te Raki by BERL (Hillmare Schulze and Konrad Hurren). http://www.maorifutures.co.nz/wpcontent/uploads/2020/06/Tokona-Te-Raki-Ka-whati-te-tai.pdf

Tyson, J. (2020). Iwi leaders partner with food service to provide kai to vulnerable whānau nationwide. Te Ao Māori News. https://www.teaomaori.news/iwi-leaders-partner-food-service-provide-kaivulnerable-whanau-nationwide

Wade, A. (2020, April 23). Watch live: Business leaders speak about how to stimulate the economy after Covid-19. New Zealand Herald. https://www.nzherald.co.nz/nz/news/article.cfm?c_id=1\&objectid=12326905

Waring, M. (1988). If women counted: A new feminist economics. MacMillan.

Wynyard, M. A. (2016). The Price of Milk: Primitive accumulation and the New Zealand Dairy Industry 1814-2014 [Unpublished PhD thesis]. University of Auckland. 